OPEN ACCESS

Edited by: Wei Zheng, Albert Einstein College of Medicine, United States

Reviewed by: Siegfried Weiss, Helmholtz Center for Infection

Research, Germany Viktor Umansky,

German Cancer Research Center (DKFZ), Germany

${ }^{*}$ Correspondence: Seth B. Coffelt seth.coffelt@glasgow.ac.uk Leo M. Carlin leo.carlin@glasgow.ac.uk

Specialty section:

This article was submitted to Cancer Immunity and Immunotherapy, a section of the journal

Frontiers in Immunology

Received: 09 May 2019

Accepted: 29 July 2019

Published: 14 August 2019

Citation:

Mackey JBG, Coffelt SB and Carlin LM (2019) Neutrophil Maturity in Cancer. Front. Immunol. 10:1912. doi: 10.3389/fimmu.2019.01912

\section{Neutrophil Maturity in Cancer}

\author{
John B. G. Mackey ${ }^{1,2}$, Seth B. Coffelt ${ }^{1,2 *}$ and Leo M. Carlin ${ }^{1,2 *}$ \\ ${ }^{1}$ Institute of Cancer Sciences, University of Glasgow, Glasgow, United Kingdom, ${ }^{2}$ Cancer Research UK Beatson Institute, \\ Glasgow, United Kingdom
}

Neutrophils are implicated in almost every stage of oncogenesis and paradoxically display anti- and pro-tumor properties. Accumulating evidence indicates that neutrophils display diversity in their phenotype resulting from functional plasticity and/or changes to granulopoiesis. In cancer, neutrophils at a range of maturation stages can be identified in the blood and tissues (i.e., outside of their developmental niche). The functional capacity of neutrophils at different states of maturation is poorly understood resulting from challenges in their isolation, identification, and investigation. Thus, the impact of neutrophil maturity on cancer progression and therapy remains enigmatic. In this review, we discuss the identification, prevalence, and function of immature and mature neutrophils in cancer and the potential impact of this on tumor progression and cancer therapy.

Keywords: neutrophil, cancer, myeloid, cancer inflammation, granulopoiesis

\section{INTRODUCTION}

Neutrophils in cancer have received very little attention until recently, despite contributing 50-70\% and $10-25 \%$ of circulating leukocytes in humans and laboratory mice, respectively (1). However, recent progress has renewed interest in these cells. In experimental cancer models, neutrophils have been implicated in nearly every stage of the oncogenic process and their role has been reviewed in detail (2-4). Neutrophils are able to mediate a broad range of anti- and pro-tumor activities from direct cancer cell killing to tumor cell proliferation, angiogenesis, metastasis, and orchestrating other immune responses. These recent studies have highlighted the complexity of neutrophils in cancer progression, with novel information on their previously unappreciated plasticity and heterogeneity. While neutrophil plasticity can be directly affected by the local microenvironment, neutrophil heterogeneity is also influenced by their maturation (5), age (6), suppressive properties (7), function [e.g., phagocytosis (8)], and reverse transendothelial migration (rTEM) (9). An underexplored aspect of this is the appearance of immature neutrophils in cancer. Differences in the phenotype and functional capacities of immature and mature neutrophil populations are being identified, and their impact on cancer progression is emerging (10). However, the influence of neutrophil maturity on their anti- or pro-tumor properties remains understudied. In this review, we focus on the functional properties and relevance of immature neutrophils in cancer. We discuss methods used to identify neutrophils of different maturation states and explore their limitations. Finally, we postulate the impact that neutrophil maturity may have on the efficacy of cancer therapies.

\section{GRANULOPOIESIS}

After birth, neutrophil production occurs primarily in the bone marrow (BM) where they are derived from hematopoietic stem cells (HSCs). During neutrophil differentiation in mice and humans the nucleus progresses from a banded to segmented morphology, allowing the 
identification of neutrophils at distinct stages of maturity (11). Stages of neutrophil differentiation are also characterized by their unique expression of the transcription factors PU.1 and CCAAT enhancer binding protein (C/EBP)- $\alpha$ (12), C/EBP $\beta$ (13), and $\mathrm{C} / \mathrm{EBP} \varepsilon(14)$. Mature neutrophils are mitotically inactive with cell cycle arrest occurring during the myelocyte to metamyelocyte transition (15). The post-mitotic BM transit of neutrophils and release into the circulation takes between 5 and 8 days in humans (16) and 1-2 days in mice during homeostasis (17). Neutrophil granules, termed azurophillic (primary), specific (secondary), and gelatinase (tertiary), in addition to secretory vesicles, are formed at specific stages of neutrophil differentiation. Each granule type is composed of distinct proteins synthesized at the time of formation (18) and granules are released in reverse sequential order following neutrophil activation (19). As such, the proteome composition of immature and mature neutrophils is greatly different. It is important to also acknowledge that in disease, including cancer, granulopoiesis can occur outside of the medullary spaces of the BM, termed extramedullary hematopoiesis (EMH); however, little is known about the mechanisms regulating EMH and its influence on neutrophil development (20).

\section{ISOLATION AND IDENTIFICATION OF IMMATURE NEUTROPHILS}

Despite the extensive data on neutrophils and their functions in homeostasis and disease, they remain a challenging cell population to study largely due to their short half-life $[\sim 18.5 \mathrm{~h}$ in the circulation of humans during homeostasis (16)] and propensity for priming and activation. While neutrophil life span can be increased following their activation and extravasation, a small window of opportunity for in vitro experimentation remains in comparison to other cell types. Neutrophil properties derived from ex vivo experimentation can be difficult to accurately interpret and apply to their behavior in vivo. Developments of in vivo imaging techniques and identification of neutrophils (e.g., via in vivo injection of fluorescently conjugated anti-Ly6G antibody, clone 1A8 (9, 21,22 ) and fluorescent reporter mice (23) have allowed their investigation without possible ex vivo manipulation-induced artifacts; however, these approaches still have their own caveats for example the undetermined function for Ly6G (23-25). Importantly, experimental analysis of immature neutrophil populations is an even greater challenge.

\section{Density Properties}

Neutrophil density changes during development as a result of their increased granularity and changes in cell size (26). Therefore, density gradient purification is useful for enriching neutrophil populations at certain stages of maturation and allows for down-stream analysis. Immature neutrophils are typically found in low density (LD) fractions, whereas mature neutrophils are found in the normal/high density (N/HD) fractions (5) (Tables 1, 2). Nevertheless, the neutrophil populations obtained by density gradient purification are not pure as N/HDNs can
TABLE 1 | Methods for the identification of immature neutrophils in humans.

\begin{tabular}{|c|c|c|}
\hline Immature population & $\begin{array}{l}\text { Feature/Cell surface } \\
\text { markers }\end{array}$ & References \\
\hline $\begin{array}{l}\text { Metamyelocyte } \\
\text { Myelocyte }\end{array}$ & Sysmex IG & $(27)$ \\
\hline Myeloblast to mature & Low density & (28) \\
\hline Immature & CD10 ${ }^{\text {Low }}$ CD15 ${ }^{\text {High }}$ & (29) \\
\hline Myelocyte to band & $\begin{array}{l}\text { Low density } \\
\text { SSC }^{\text {High }} \text { CD } 66 b^{\text {Pos }}{ }^{\text {CD } 125^{\mathrm{Neg}}} \\
\text { Pappenheim staining }\end{array}$ & (30) \\
\hline $\begin{array}{l}\text { Myeloblast } \\
\text { Promyelocyte }\end{array}$ & $\begin{array}{l}\text { Blood smears } \\
\text { Celltac ES } \\
\text { hematology analyser }\end{array}$ & (31) \\
\hline Band & CD10 ${ }^{\text {Dim }}$ CD16 ${ }^{\text {Dim }}$ & $(32)$ \\
\hline Band & CD10 Dim CD16 Dim & (33) \\
\hline $\begin{array}{l}\text { Metamyelocyte } \\
\text { Myelocyte } \\
\text { Promyelocyte }\end{array}$ & CD11b ${ }^{\text {Low }}$ CD16 ${ }^{\text {Pos }}$ & (34) \\
\hline Immature & $\begin{array}{l}\text { BM resident } \\
\text { Nuclear Morphology }\end{array}$ & (35) \\
\hline $\begin{array}{l}\text { Metamyelocyte } \\
\text { Myelocyte } \\
\text { Promyelocyte }\end{array}$ & $\begin{array}{l}\text { XE 2100, Sysmex } \\
\text { hematology analyser }\end{array}$ & (36) \\
\hline Band & CD16 ${ }^{\text {Dim }}$ & $(37)$ \\
\hline Metamyelocyte & CD35 ${ }^{\mathrm{Neg}}$ CD49dPos & (38) \\
\hline $\begin{array}{l}\text { Metamyelocyte } \\
\text { Myelocyte } \\
\text { Promyelocyte }\end{array}$ & $\begin{array}{l}\text { Coulter Actdiff } 5 \text { automated } \\
\text { hematology analyser }\end{array}$ & (39) \\
\hline Immature & $\begin{array}{l}\text { Nuclear morphology } \\
\text { Number } \\
\text { of nucleoli Cytoplasmic } \\
\text { granularity }\end{array}$ & $(40)$ \\
\hline
\end{tabular}

become LDNs following activation (55), making interpretation of the functional properties of neutrophil maturity challenging by this technique. For instance, LDNs isolated from the peripheral blood of $4 \mathrm{~T} 1$ tumor-bearing mice make up $\sim 40 \%$ of morphologically mature neutrophils (5), LDNs obtained from the peripheral blood of mice bearing breast cancer liver metastasis were composed of $80 \%$ neutrophils with an immature nuclear morphology (56), and the nuclear morphology of LDNs from lung cancer patients represent both mature and immature neutrophils (5). Overall, this technique can be useful for enriching neutrophil populations; although, more specific methods of identification of neutrophil maturity are required for accurate interpretation of downstream functional analysis.

\section{Morphology and Cell Surface Markers}

Nuclear segmentation is considered accurate for immature neutrophil identification in the peripheral blood of cancer patients (57) and mouse models of cancer (58) (Tables 1, 2). However, cells cannot be isolated by this method for downstream experimentation. A major hindrance in neutrophil biology is the lack of a specific and robust marker of neutrophil maturity. Changes in cell surface receptor expression during maturation, such as the CXCR4:CXCR2 axis $(59,60)$, can be used to separate 
TABLE 2 | Methods for the identification of immature neutrophils in mice.

\begin{tabular}{|c|c|c|}
\hline Immature population & $\begin{array}{l}\text { Feature/Cell surface } \\
\text { markers }\end{array}$ & References \\
\hline $\begin{array}{l}\text { Myelocyte } \\
\text { Meta-myelocyte }\end{array}$ & Nuclear morphology & $(41)$ \\
\hline Myeloblast & Nuclear morphology & $(42)$ \\
\hline Pro-myelocyte to band & Nuclear morphology & $(43)$ \\
\hline $\begin{array}{l}\text { Band } \\
\text { Meta-myelocyte }\end{array}$ & $\begin{array}{l}\text { Nuclear Morphology } \\
\text { Gr-1 }{ }^{\text {Low }} \text { BrdU Dim }\end{array}$ & $(17)$ \\
\hline $\begin{array}{l}\text { Mature } \\
\text { Myelocyte } \\
\text { Promyelocyte }\end{array}$ & $\begin{array}{l}\text { Gr-1 }{ }^{\text {Hi CD } 11 b \text { Pos }} \\
\text { Gr-1 }{ }^{\text {Low }} \text { CD11b Pos }\end{array}$ & $(44)$ \\
\hline Band/mature & Nuclear morphology & $(45)$ \\
\hline Immature & $\begin{array}{l}\text { Reduced MPO } \\
\text { Reduced oxidative burst }\end{array}$ & $(46)$ \\
\hline Band & $\begin{array}{l}\text { CD11bPos Gr- } \\
{ }_{1}^{\text {Pos }} \text { Ly } 6 G \text { Pos }_{\text {Ly } 6 C^{\text {Pos }} \text { MDL- }} \\
{ }_{1}^{\text {Pos }}\end{array}$ & $(47)$ \\
\hline Band & Ly6G'Int & $(21)$ \\
\hline Immature & Ly6GLow/NegCD101Neg & $(48)$ \\
\hline $\begin{array}{l}\text { Immature } \\
\text { Myelocyte } \\
\text { Pro-myelocyte }\end{array}$ & $\begin{array}{l}\text { Gr-1 }{ }^{\text {High }} \text { CD11 } b_{\text {Low }} \\
\text { Gr-1 }{ }^{\text {Int }} \text { CD11b Int }\end{array}$ & $(49)$ \\
\hline $\begin{array}{l}\text { Mature } \\
\text { Band } \\
\text { Myelocyte }\end{array}$ & $\begin{array}{l}\mathrm{Gr}-1^{\mathrm{Hi}} \\
\mathrm{Gr}-1 \text { Low }\end{array}$ & $(50)$ \\
\hline Neutrophil Precursors & $\begin{array}{l}\text { Ly6G }^{\text {Low }} \text { Ly6B }^{\text {Int }} \text { CD115 } \\
\text { CD11 } 1 b^{\text {Pos }} \text { CD133 }\end{array}$ & $(51)$ \\
\hline $\begin{array}{l}\text { Mature } \\
\text { Band }\end{array}$ & $\begin{array}{l}\mathrm{Gr}-1^{\mathrm{Hi}} \mathrm{CD} 11 b^{\mathrm{Low}-\mathrm{Hi}} \\
\mathrm{Gr}-1^{\mathrm{Low}-\mathrm{Hi}} \mathrm{CD} 11 \mathrm{~b} \text { Low-Hi }\end{array}$ & $(52)$ \\
\hline $\begin{array}{l}\text { Mature } \\
\text { Band } \\
\text { Metamyelocyte } \\
\text { Myelocyte }\end{array}$ & $\begin{array}{l}\text { Ly6G }{ }^{\mathrm{Hi}} \text { CD11bPos } \\
\text { Ly6G }{ }^{\text {Low }} \text { CD11b Pos }\end{array}$ & $(53)$ \\
\hline $\begin{array}{l}\text { Mature } \\
\text { Band } \\
\text { Myeloblast } \\
\text { Pro-myelocyte } \\
\text { Myelocytes } \\
\text { Meta-myelocyte }\end{array}$ & 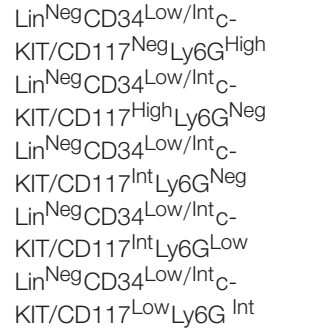 & $(13)$ \\
\hline $\begin{array}{l}\text { Metamyelocyte } \\
\text { Myelocyte } \\
\text { Promyelocyte } \\
\text { Band } \\
\text { Metamyelocyte } \\
\text { Mature }\end{array}$ & $\begin{array}{l}\mathrm{Gr}-1^{\mathrm{Int}} \mathrm{CD} 11 \mathrm{~b}^{\mathrm{Int}} \\
\mathrm{Gr}-1^{\mathrm{Hi}} \mathrm{CD} 11 b^{\mathrm{Low}} \\
\mathrm{Gr}-1^{\mathrm{Hi}} \mathrm{CD} 11 b^{\mathrm{Hi}}\end{array}$ & $(54)$ \\
\hline
\end{tabular}

immature and mature neutrophils (48) (Table 2). However, these surface receptors are prone to alteration following neutrophil activation [e.g., CD11b:CD18 (61)], tissue migration [e.g., CD62L $(6,62,63)]$, and aging [e.g., CXCR4 (6)], resulting in a major challenge in the identification of efficient markers of maturity. In mice, immature and mature neutrophils can accurately be identified as $\mathrm{Ly} 6 \mathrm{G}^{\text {Int/Low }} \mathrm{CD} 11 \mathrm{~b}^{\text {Pos }}$ and $\mathrm{Ly} 6 \mathrm{G}^{\text {High }} \mathrm{CD} 11 \mathrm{~b}^{\text {Pos }}$ respectively $(13,21,51)$ (Table 2$)$. However, the limitations of using Ly6G as a maturity marker include relatively small differences in expression of this molecule between immature and mature neutrophils, compounding the technical issues associated with fluorescence intensity comparisons in some readouts. Despite this, recently identified markers of neutrophil maturity with larger differences in expression, for example CD101 (48), could be useful candidates for development of fluorescent reporter models and in vivo identification. Here, $\mathrm{CD} 101$ expression can be used to identify CD101 ${ }^{\mathrm{Neg}}$ (immature) and $\mathrm{CD} 101^{\mathrm{Pos}}$ (mature) neutrophils (48); however, this marker requires further validation to ensure its accuracy in a wide range of pathologies. Another example is c-KIT/CD117, the expression of which has been shown to associate with neutrophil maturity in naïve mice, mice undergoing candida-induced emergency granulopoiesis (13), and a mouse model of breast cancer (64) (Table 2). However, although in the K14-Cre; $C d h 1^{\mathrm{F} / \mathrm{F}} ; \operatorname{Trp} 53^{\mathrm{F} / \mathrm{F}}$, and 4T1 mouse mammary tumor models, neutrophil c-KIT expression is enriched on immature neutrophils, it fails to completely correlate with maturation status $(58,65)$. In humans, immature and mature neutrophils are commonly identified as $\mathrm{CD} 16^{\mathrm{Low}} \mathrm{CD} 10^{\mathrm{Neg}}$ and $\mathrm{CD} 16^{\mathrm{High}} \mathrm{CD} 10^{\mathrm{Pos}}$, respectively (66) (Table 1). Expression of CD16 (FcyRIII) is initiated between the metamyelocyte and band stages of neutrophil maturation $(67,68)$. However, its expression can be reduced during apoptosis (69) and can be up-regulated on the cell surface following secretory granule cell membrane fusion (67). Distinct differences in the hematopoietic environment, local and systemic cytokine levels and the functional requirements for neutrophils will exist between naïve, emergency granulopoiesis and the more chronic "inflammation" present in cancer. Therefore, as neutrophils can exhibit plasticity in response to their environment, certain markers are likely to only be suitable in particular models and require efficient validation in each. Overall, the challenges associated with identifying and isolating populations of neutrophil maturity have hindered their study and our current understanding of their functional properties.

\section{FUNCTIONAL PROPERTIES OF MATURE AND IMMATURE NEUTROPHILS}

\section{Immature Neutrophils in Cancer}

The existence of immature neutrophils in the circulation and tissues is a consequence of cancer development in human patients and mouse models. For example, immature neutrophils are detectable in the circulation (and in some cases the primary tumors) of both injectable and transgenic mouse models of colon (70), skin (70), mammary $(5,58,71,72)$, lung cancer $(5,73)$, and mesothelioma $(\mathrm{AB} 12)(5,73)$. In humans, immature neutrophils have been described in patients with lung cancer $(5,74)$, breast cancer (5), and ovarian cancer (65).

\section{Drivers of Immature Neutrophil Appearance Outside of the Hematopoietic Niche}

Premature release from the $\mathrm{BM}$ as observed in states of emergency granulopoiesis, as reviewed by others (75), is 
considered the main reason for the presence of immature neutrophils in the circulation. Emergency granulopoiesis commonly results from increased levels of granulocyte colonystimulating factor (G-CSF; also known as CSF-3) (76) that promotes the differentiation of hematopoietic precursors down the neutrophil lineage and release of neutrophils into the circulation $(60,71,72,77)$ (Figure 1A). Production of G-CSF is controlled by interleukin (IL)-23 and IL-17 (58, 78, 79) and can be increased in many cancer models and patients $(56,58,71,72,80)$. Enhanced levels of G-CSF drive excessive production and release of neutrophils and their precursors into the circulation, leading to neutrophilia $(58,71,72,81)$. G-CSF is dispensable for emergency granulopoiesis and other cytokines, including granulocyte/macrophage (GM)-CSF (also known as CSF-2) $(43,75)$, can drive neutrophil production and release. Furthermore, neutrophil precursors can seed distant tissues and produce neutrophils in situ, as has been observed in cancer patients (82) (Figure 1B). TGF $\beta$ is another cytokine that favors the presence of immature neutrophils, since its inhibition converts neutrophils to a mature phenotype in transplantable models of mesothelioma (73). The N1/N2 nomenclature-which mirrors the Th1/Th2 nomenclature of $\mathrm{T}$ helper cells-was coined in this study based on the influence of TGF $\beta$ to modulate neutrophil phenotype and function. Neutrophils were named pro-tumor N2 cells or anti-tumor N1 cells after Th1/Th2 CD4 T cells and M1/M2 macrophages. However, evidence that neutrophils mediate type 1 or type 2 immunity is lacking, and additionally, how these phenotypes relate to the neutrophils found in patients is still under investigation [recently reviewed in Shaul and Fridlender (83)]. Therefore, this nomenclature may be confusing in the context of cancer at this time and future work will determine its appropriateness. In contrast to TGF $\beta$, expression of Type 1 interferons (IFN $\alpha$ and IFN $\beta$ ) in tumors favors mature neutrophils over immature neutrophils (57). Most likely, there are many other tumor-derived factors that influence neutrophil maturity and their discovery could lead to opportunities for therapeutic intervention.

\section{Functional Properties of Immature Neutrophils}

The degree of functional difference between immature and mature neutrophils remains an open question in the field. Due to the importance of neutrophil differentiation in their effector mechanisms, (e.g., production of granule proteins), there is a strong argument for functional differences. Immature neutrophils may in many cases fall under the myeloidderived suppressor cell (MDSC) umbrella, as these cells have been reported to inhibit $\mathrm{T}$ cells. MDSCs encompass a wide range of granulocytic and monocytic cell types at different stages of differentiation. Polymorphonuclear (PMN)-MDSCs are widely considered to be an immature neutrophil population, but methods for their identification, including with anti-Gr-1 (clone RB6-8C5) antibody-which recognizes both Ly6C and Ly6G epitopes-fail to accurately discriminate between mature and immature cells $(84,85)$. Recently, the classification and identification of MDSC subsets based on their phenotype and morphology has been improved, but these are still identified as CD $11 b^{\text {Pos }}{ }^{\text {Ly6 }} \mathrm{C}^{\text {Low }}$ Ly6G ${ }^{\text {Pos }}$ (84). Nevertheless, we believe that the suppressive functions of immature and mature neutrophils is a pathological response to tumorigenesis rather than a completely separate granulocytic population, as discussed by others (86-88). Therefore, we refer to PMN-MDSCs as neutrophils in this article. Ex vivo suppression assays are the most common technique for identifying and analyzing suppressive neutrophils. Findings that have used this technique are challenging to interpret as they can be influenced by neutrophil survival, cytotoxicity, neutrophil:T cell ratio, and protocols used [e.g., CD3/CD28 microbeads or antibodies (89)]. Immature (90) and mature (91) neutrophils can be suppressive; however, differences in the suppressive capacities of these populations $(66,92)$ are likely influenced by disease, model, and neutrophil isolation and identification protocols used (Figure 1D). It should also be noted that not all tumorinfiltrating immature neutrophils possess $\mathrm{T}$ cell-suppressive abilities $(93,94)$.

Immunosuppression by neutrophils is not only important for primary tumor progression, but this mechanism can also promote metastasis formation. Neutrophils can be recruited by CXCR2 ligands to dampen anti-tumor immunity in premetastatic organs so that disseminated cancer cells can evade immune destruction $(58,95,96)$. In these cases, it is the immature neutrophils that are thought to mediate immunosuppression and subsequent metastasis; although, this has not been formally shown. In addition, immature neutrophils and other myeloid progenitors can aid in the formation of the pre-metastatic niche via mechanisms other than $\mathrm{T}$ cell suppression (97-99). Interestingly, in models where immature neutrophils are absent, such as the MMTV-PyMT model of breast cancer, it is the mature neutrophils that drive metastasis (100). Together, these data indicate that neutrophil maturity may be irrelevant to their pro-metastatic functions.

ROS production is important in several neutrophil effector mechanisms including their microbicidal (101), phagocytic (102) and suppressive capacity and contributes to neutrophil antiand pro-tumor functions [reviewed in Ohl and Tenbrock (103)]. One such pro-tumor function of neutrophil ROS in cancer is their promotion of tumor initiation at states of inflammation by damaging proliferating epithelial cells (104). In relation to neutrophil maturity the production of ROS can be variable between immature and mature cells. For example, immature neutrophils ( $\mathrm{Ly} 6 \mathrm{G}^{\mathrm{Pos}} \mathrm{CD} 101^{\mathrm{Neg}}$ ) display reduced ROS production compared to mature $\left(\mathrm{Ly} 6 \mathrm{G}^{\mathrm{Pos}} \mathrm{CD} 101^{\mathrm{Pos}}\right.$ ) in a mouse orthotopic pancreatic cancer model (48). Similarly, in a range of other transplantable mouse cancer models, LDNswhich are enriched in morphologically immature neutrophilshave reduced ROS production (5). However, the amount of ROS production may be context dependent and reliant on metabolism. In tumor-free mice ( $\mathrm{Ly} 6 \mathrm{G}^{\text {Int }} \mathrm{c}-\mathrm{Kit}^{\mathrm{Pos}}$ ) and ovarian cancer patients $\left(\mathrm{CD} 10^{\mathrm{Int}}\right)$, immature neutrophils are dependent on oxidative mitochondrial metabolism rather than glycolysis, for ROS production (65). Recently, LDNs from mice bearing 4T1 mammary tumor liver metastasis have also been shown to have an increased oxidative metabolism (56). This dependency may have implications in the glucose-limited tumor microenvironment 


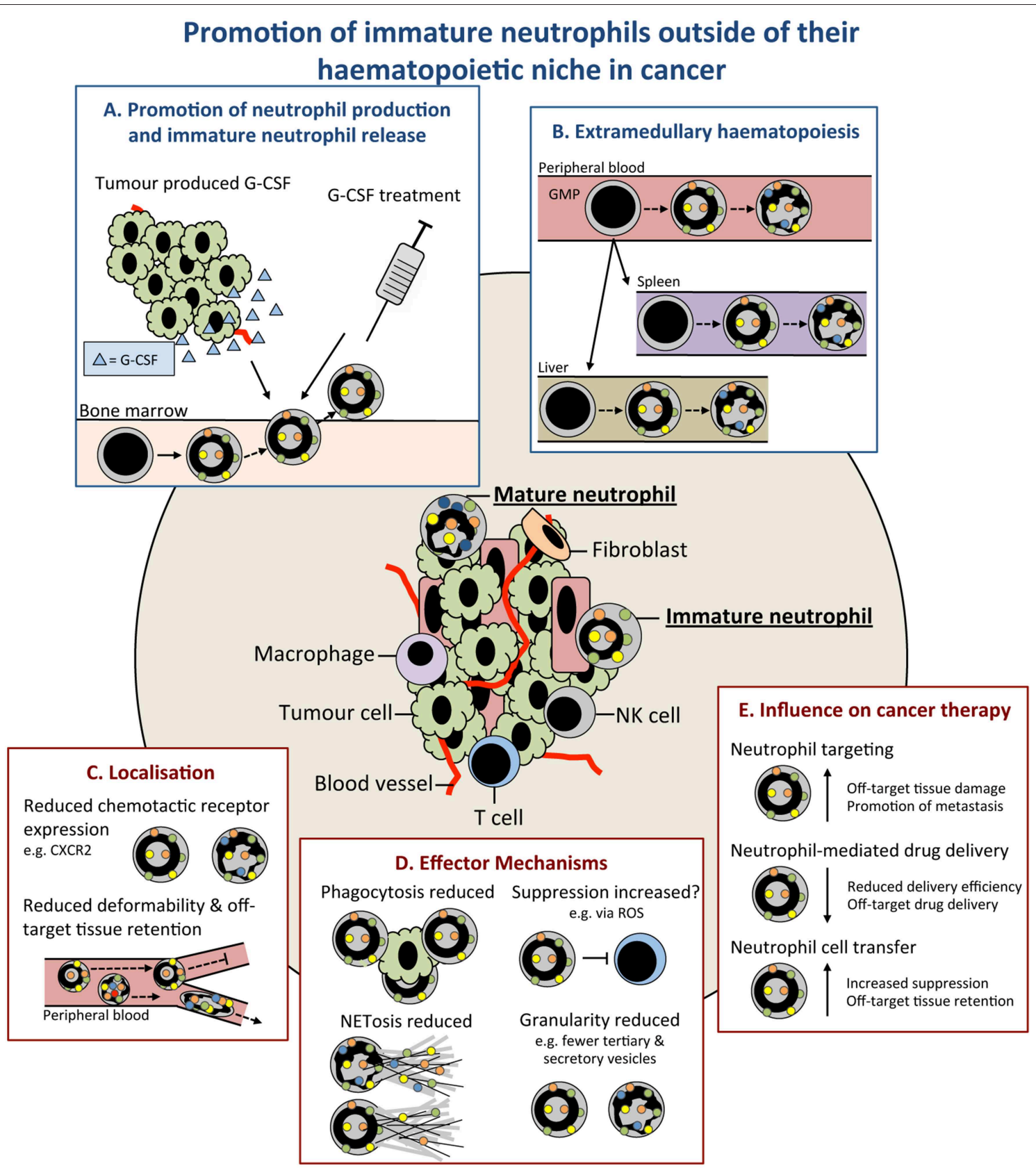

\section{Influence on tumour progression \& cancer therapy}

FIGURE 1 | Immature neutrophils are present in cancer and have an altered functional capacity compared to mature that may influence tumor progression. Immature neutrophils can be present and significantly increased in the peripheral blood and tissues of cancer patients. This increase may result from: (A) promotion of their early release from their bone marrow (BM) haematopoietic niche by increased systemic chemokines, such as granulocyte colony-stimulating (G-CSF), e.g., tumor produced or as therapy. (B) release of neutrophil precursors from the BM and their extramedullary proliferation in the circulation or tissues. Immature neutrophils may have both anti- and pro-tumor properties. These include (C) altered localization resulting from their differential cell surface marker expression influencing their chemotactic capacity and/or less segmented nuclear morphology compared to mature neutrophils reducing their deformability and (D) different functional capacity compared to mature neutrophils including their reduced phagocytic capacity, altered suppressive properties, reduced NETosis, and reduced granularity. (E) Together, these differences in the properties and functions of immature neutrophils could lead to their negative influence when targeting neutrophils in cancer therapy. G-CSF, colony stimulating factor-3; GMP, granulocyte monocyte progenitor; ROS, reactive oxygen species; NET, neutrophil extracellular trap; NK, natural killer cell.

and affect neutrophil function (65). Therefore, while immature neutrophils can have reduced ROS production compared to mature neutrophils, this appears to be dependent on stimulus, their localization and the tissue microenvironment. 
Neutrophil extracellular traps (NETs) are extracellular fibers composed of nuclear, mitochondrial, cytoplasmic and granule contents that can be released by neutrophils following their activation (105). NETs can capture circulating cancer cells in the mouse lung promoting their extravasation and metastasis formation $(106,107)$. Neutrophils can also aid in formation of the omental pre-metastatic niche and capture of circulating ovarian cancer cells, promoting their metastasis at this site (108). The ability of immature human neutrophil populations to release NETs is reduced following interferon priming (35) (Figure 1D). In addition, when isolated from the peripheral blood of acute myeloid leukemia (AML) patients, morphologically immature neutrophils show decrease capacity for NET formation following phorbol 12-myristate 13-acetate (PMA) stimulation (109). As NETs have been proposed to arise from the inability of terminally differentiated neutrophils to re-enter mitosis (110), it could be inferred that the increased mitotic capacity of immature populations contributes to these differences. ROS contribute to NETosis by promoting granule release and rupture of the nuclear envelope, as highlighted by the inability of neutrophils from chronic granulomatous disease patients to undergo NETosis $(111,112)$. Differences in ROS production with neutrophil maturity may also influence NETosis (65). Differences in granule composition of neutrophils at different maturity may also influence the functional capacity of their NETs. The tertiary granule component MMP-9 (113) has been implicated in NETinduced dormant cancer cell reactivation (114) and its possible reduced abundance in banded neutrophils and earlier neutrophil precursors present in cancer could reduce their ability to promote this reactivation.

Multiple studies have indicated a reduced migratory capacity of immature compared to mature neutrophils $(5,48)$ (Figure 1C). This may result from lower expression of chemokine receptors, such as CXCR1 and CXCR2 (30), and other genes involved in chemotaxis (48). In mice, proliferating

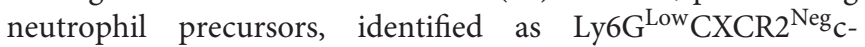
$\mathrm{Kit}^{\mathrm{Pos}} \mathrm{CXCR} 4{ }^{\mathrm{Pos}}$, have reduced migration to laser-induced damage (48). High CXCR2 expression by neutrophils has been associated with poor outcome in human pancreatic ductal adenocarcinoma (PDAC) patients (95). Inhibition of CXCR2 in a mouse model of PDAC reduces neutrophil migration and delays tumor progression (95). Banded nuclear morphology, and thus reduced deformability, may promote immature neutrophil sequestration in capillaries and reduce their migratory capacity (115); although, banded nuclear morphology in immature human neutrophils does not affect transendothelial migration (TEM) when compared to segmented neutrophils ex vivo (62) (Figure 1C). It is therefore conceivable that their increased sequestration in off target tissues and ability to undergo TEM may result in unwanted immature neutrophil accumulation and the promotion of inflammation and/or metastasis. Additionally, neutrophil spontaneous migration is increased in the early compared to late stages of cancer in a mouse orthotopic lung cancer model (116). These changes in neutrophil function with tumor progression are present in BM cells, suggesting altered granulopoiesis over time (116). Therefore, while further investigation is required, differential trafficking of immature neutrophils could have the capacity to both antagonize and promote tumor development dependent on their localization.

The phagocytic capacity of immature, compared to mature, neutrophils is also reduced $(5,48)$ and could result from their altered cell surface receptor expression and decreased ROS production (Figure 1D). Fc receptors (FcRs) are important in mediating phagocytosis (117) with decreased expression of CD16 likely influencing their phagocytic capacity. Furthermore, immature neutrophils (CD16 ${ }^{\text {Int }}$ ) are unable to kill tumor cells via Fc $\gamma$ RI, but exhibit cytotoxicity via FcoRI (118). Activation of FcRs, integrins and G-protein coupled receptors (GPCRs) can trigger neutrophil ROS production and its extracellular or intracellular release into the phagolysosome, as reviewed in more detail by others $(102,119)$. Unsurprisingly, immature neutrophils have also been shown to have an increased life span and can mature ex vivo (120). It will be interesting to determine if neutrophil maturation after their release from the $\mathrm{BM}$ contributes to heterogeneity within the mature neutrophil population. However, despite differences in the functional capacity of immature and mature neutrophils, they are still capable of mediating innate immune functions (120). Overall, the effect of neutrophil maturity in cancer remains enigmatic and further investigation, coupled with accurate identification, is required.

\section{NEUTROPHIL MATURITY IN ANTI-CANCER THERAPY}

Immunotherapy has shown great promise in cancer; however, only a minority of patients respond to certain therapies (121) and combinatorial therapies targeting a broad range of immune populations may be more beneficial. Therapies targeting neutrophils have received relatively little attention (Figure 1E). While the direct effect of therapies on neutrophils at different stages of maturation has not been investigated, we can consider ways in which the properties of immature neutrophils are relevant.

Neutrophils recruited to the tumor via CXCR2 can aid tumor progression (122) and inhibition of CXCR1 and CXCR2 has shown promise in mouse models (95) and human cancers (123). As CXCR2 expression increases with neutrophil maturation (48) inhibitors of CXCR2 may differentially influence immature and mature neutrophils affecting their efficacy. Therapies targeting immunosuppressive neutrophils enhance responses to checkpoint blockade by promoting tumor infiltration by $\mathrm{T}$ cells in mouse models (124-127). A greater understanding of the maturity composition of these cells could better aid targeting of this population. Furthermore, tyrosine kinase inhibitors that target the hepatocyte growth factor (HGF) receptor, cMET (e.g., Cabozantinib and Capmatinib) can extend survival by influencing neutrophil behavior in mouse melanoma and PTEN/p53-deficient prostate cancer models (128, 129). As tyrosine kinases (e.g., Bruton's tyrosine kinase; BTK) are important in regulating neutrophil development (49) and in neutrophil integrin signaling (130) it is possible that their inhibitors have altered effects on neutrophils of 
different maturity. Similarly, monoclonal antibody (mAb) based therapies, for example anti-gp75 (TA99) (131), anti-HER2 (Trastuzumab) (131), and anti-SIRP $\alpha$ (KWAR23) (132, 133), promote neutrophil-mediated destruction of cancer cells. The reduced phagocytic capacity (48) of immature neutrophils and differences in their FcR expression (118) may reduce the efficacy of these therapies. Furthermore, these properties may hamper their ability to deliver therapeutics, such as in nanoparticles (134), to the tumor (Figure 1E). Finally, adoptively transferred neutrophils can aid in the killing of cancer cells (135) and can be isolated from G-CSF-treated donors (136) (Figure 1E). Here, the activation (137) and potential retention of transferred immature neutrophils in off-target organs [e.g., the lung (138)] needs to be considered. In addition, G-CSF-driven immature neutrophil release, neutrophil accumulation, and alterations to neutrophil function in cancer $(66,100,139)$ need to be further deliberated when treating neutropenic cancer patients with G-CSF $(140,141)$.

\section{CONCLUSIONS}

To gain an accurate understanding of maturity on neutrophil functional capacity, consensus protocols for identification of neutrophil maturity are urgently required. However, as protocols and markers may not be transferable between models, detailed confirmation of maturity in each is essential (e.g., associated nuclear morphology, transcriptomics, proteomics, and surface protein expression data) allowing for proper comparison. Functional investigation needs to be further driven by in

\section{REFERENCES}

1. Mestas J, Hughes CC. Of mice and not men: differences between mouse and human immunology. J Immunol. (2004) 172:2731-8. doi: 10.4049/jimmunol.172.5.2731

2. Coffelt SB, Wellenstein MD, de Visser KE. Neutrophils in cancer: neutral no more. Nat Rev Cancer. (2016) 16:431-46. doi: 10.1038/nrc.2016.52

3. Grecian R, Whyte MKB, Walmsley SR. The role of neutrophils in cancer. $\mathrm{Br}$ Med Bull. (2018) 128:5-14. doi: 10.1093/bmb/ldy029

4. Galdiero MR, Varricchi G, Loffredo S, Mantovani A, Marone G. Roles of neutrophils in cancer growth and progression. J Leukoc Biol. (2018) 103:457-64. doi: 10.1002/JLB.3MR0717-292R

5. Sagiv JY, Michaeli J, Assi S, Mishalian I, Kisos H, Levy L, et al. Phenotypic diversity and plasticity in circulating neutrophil subpopulations in cancer. Cell Rep. (2015) 10:562-73. doi: 10.1016/j.celrep.2014.12.039

6. Casanova-Acebes M, Pitaval C, Weiss LA, Nombela-Arrieta C, Chevre R, A-González N, et al. Rhythmic modulation of the hematopoietic niche through neutrophil clearance. Cell. (2013) 153:1025-35. doi: 10.1016/j.cell.2013.04.040

7. Youn JI, Nagaraj S, Collazo M, Gabrilovich DI. Subsets of myeloid-derived suppressor cells in tumor-bearing mice. J Immunol. (2008) 181:5791802. doi: 10.4049/jimmunol.181.8.5791

8. Hellebrekers P, Hietbrink F, Vrisekoop N, Leenen LPH, Koenderman L. Neutrophil functional heterogeneity: identification of competitive phagocytosis. Front Immunol. (2017) 8:1498. doi: 10.3389/fimmu.2017. 01498

9. Woodfin A, Voisin MB, Beyrau M, Colom B, Caille D, Diapouli FM, et al. The junctional adhesion molecule JAM-C regulates polarized transendothelial migration of neutrophils in vivo. Nat Immunol. (2011) 12:761-9. doi: 10.1038/ni.2062 vivo investigation to remove concerns associated with ex vivo manipulation. Of particular importance, investigating the localization and suppressive capacity of immature neutrophils in situ will aid in determining their influence on immunotherapy. Furthermore, more research on immature neutrophils in cancer patients should be carried out to determine where these cells appear. Correlations between immature neutrophils and mutational drivers need investigation to understand how these cells occur outside the bone marrow and to identify additional biomarkers of disease. Changes in neutrophil maturation status before, during and after anti-cancer therapy may provide insight into how these cells are regulated. Taken together, the available evidence suggests immature neutrophils in cancer inevitably influence tumor development and we emphasize the importance of improving methodologies for their study.

\section{AUTHOR CONTRIBUTIONS}

JM, SC, and LC wrote and edited the manuscript.

\section{FUNDING}

This work was supported by Core funding from Cancer Research UK (A23983 and A17196 to LC), Cancer Research UK Glasgow Center (A25142 to SC), Breast Cancer Now (2018JulPR1101 to SC), Wellcome Trust $(208990 / \mathrm{Z} / 17 / \mathrm{Z}$ to SC), Tenovus Scotland (Project S17-17 to SC).
10. Liu Y, Wei G, Cheng WA, Dong Z, Sun H, Lee VY, et al. Targeting myeloidderived suppressor cells for cancer immunotherapy. Cancer Immunol Immunother. (2018) 67:1181-95. doi: 10.1007/s00262-018-2175-3

11. Pillay J, Tak T, Kamp VM, Koenderman L. Immune suppression by neutrophils and granulocytic myeloid-derived suppressor cells: similarities and differences. Cell Mol Life Sci. (2013) 70:3813-27. doi: 10.1007/s00018-013-1286-4

12. Zhang DE, Zhang P, Wang ND, Hetherington CJ, Darlington GJ, Tenen DG. Absence of granulocyte colony-stimulating factor signaling and neutrophil development in CCAAT enhancer binding protein alpha-deficient mice. Proc Natl Acad Sci USA. (1997) 94:569-74. doi: 10.1073/pnas.94.2.569

13. Satake S, Hirai H, Hayashi Y, Shime N, Tamura A, Yao H, et al. $\mathrm{C} / \mathrm{EBP} \beta$ is involved in the amplification of early granulocyte precursors during candidemia-induced "emergency" granulopoiesis. J Immunol. (2012) 189:4546-55. doi: 10.4049/jimmunol.1103007

14. Yamanaka R, Barlow C, Lekstrom-Himes J, Castilla LH, Liu PP, Eckhaus $\mathrm{M}$, et al. Impaired granulopoiesis, myelodysplasia, and early lethality in CCAAT/enhancer binding protein epsilon-deficient mice. Proc Natl Acad Sci USA. (1997) 94:13187-92. doi: 10.1073/pnas.94.24.13187

15. Theilgaard-Monch K, Jacobsen LC, Borup R, Rasmussen T, Bjerregaard MD, Nielsen FC., et al. The transcriptional program of terminal granulocytic differentiation. Blood. (2005) 105:1785-96. doi: 10.1182/blood-2004-08-3346

16. Lahoz-Beneytez J, Elemans M, Zhang Y, Ahmed R, Salam A, Block M, et al. Human neutrophil kinetics: modeling of stable isotope labeling data supports short blood neutrophil half-lives. Blood. (2016) 127:34318. doi: 10.1182/blood-2016-03-700336

17. Basu S, Hodgson G, Katz M, Dunn AR. Evaluation of role of GCSF in the production, survival, and release of neutrophils from bone marrow into circulation. Blood. (2002) 100:854-61. doi: 10.1182/blood.V100. 3.854 
18. Cowland JB, Borregaard N. Granulopoiesis and granules of human neutrophils. Immunol Rev. (2016) 273:11-28. doi: 10.1111/imr. 12440

19. Hager M, Cowland JB, Borregaard N. Neutrophil granules in health and disease. J Intern Med. (2010) 268:2534. doi: 10.1111/j.1365-2796.2010.02237.x

20. Johns JL, Christopher MM. Extramedullary hematopoiesis: a new look at the underlying stem cell niche, theories of development, and occurrence in animals. Vet Pathol. (2012) 49:508-23. doi: 10.1177/0300985811432344

21. Deniset JF, Surewaard BG, Lee WY, Kubes P. Splenic Ly6G(high) mature Ly6G(int) immature neutrophils contribute to eradication of S. pneumoniae. J Exp Med. (2017) 214:1333-50. doi: 10.1084/jem.20161621

22. Daley JM, Thomay AA, Connolly MD, Reichner JS, Albina JE. Use of Ly6Gspecific monoclonal antibody to deplete neutrophils in mice. J Leukoc Biol. (2008) 83:64-70. doi: 10.1189/jlb.0407247

23. Hasenberg A, Hasenberg M, Mann L, Neumann F, Borkenstein L, Stecher $M$, et al. Catchup: a mouse model for imaging-based tracking and modulation of neutrophil granulocytes. Nat Methods. (2015) 12:44552. doi: 10.1038/nmeth.3322

24. Wang JX, Bair AM, King SL, Shnayder R, Huang YF, Shieh CC, et al. Ly6G ligation blocks recruitment of neutrophils via a $\beta 2$-integrin-dependent mechanism. Blood. (2012) 120:1489-98. doi: 10.1182/blood-2012-01-40 4046

25. Yipp BG, Kubes P. Antibodies against neutrophil LY6G do not inhibit leukocyte recruitment in mice in vivo. Blood. (2013) 121:241-2. doi: 10.1182/blood-2012-09-454348

26. Cowland JB, Borregaard N. Isolation of neutrophil precursors from bone marrow for biochemical and transcriptional analysis. I Immunol Methods. (1999) 232:191-200. doi: 10.1016/S0022-1759(99)00176-3

27. Bernstein LH, Rucinski J. Measurement of granulocyte maturation may improve the early diagnosis of the septic state. Clin Chem Lab Med. (2011) 49:2089-95. doi: 10.1515/CCLM.2011.688

28. Bjerregaard MD, Jurlander J, Klausen P, Borregaard N, Cowland JB. The in vivo profile of transcription factors during neutrophil differentiation in human bone marrow. Blood. (2003) 101:432232. doi: 10.1182/blood-2002-03-0835

29. Blazkova J, Gupta S, Liu Y, Gaudilliere B, Ganio EA, Bolen CR, et al. Multicenter systems analysis of human blood reveals immature neutrophils in males and during pregnancy. J Immunol. (2017) 198:247988. doi: 10.4049/jimmunol.1601855

30. Brandau S, Trellakis S, Bruderek K, Schmaltz D, Steller G, Elian $\mathrm{M}$, et al. Myeloid-derived suppressor cells in the peripheral blood of cancer patients contain a subset of immature neutrophils with impaired migratory properties. J Leukoc Biol. (2011) 89:311-7. doi: 10.1189/jlb.031 0162

31. Che YQ, Shen D, Zhang SM, Qi J. Identification of immature granulocytes in cancer chemotherapy patients by cell counting vs. microscopic examination of blood smears. Mol Clin Oncol. (2014) 2:207-11. doi: 10.3892/mco.2014.243

32. Demaret J, Venet F, Friggeri A, Cazalis MA, Plassais J, Jallades L, et al. Marked alterations of neutrophil functions during sepsis-induced immunosuppression. J Leukoc Biol. (2015) 98:1081-90. doi: 10.1189/jlb.4A0415-168RR

33. Guerin E, Orabona M, Raquil MA, Giraudeau B, Bellier R, Gibot $\mathrm{S}$, et al. Circulating immature granulocytes with T-cell killing functions predict sepsis deterioration*. Crit Care Med. (2014) 42:2007-18. doi: 10.1097/CCM.0000000000000344

34. Makoni M, Eckert J, Anne Pereira H, Nizet V, Lawrence SM. Alterations in neonatal neutrophil function attributable to increased immature forms. Early Hum Dev. (2016) 103:1-7. doi: 10.1016/j.earlhumdev.2016.05.016

35. Martinelli S, Urosevic M, Daryadel A, Oberholzer PA, Baumann C, Fey MF, et al. Induction of genes mediating interferon-dependent extracellular trap formation during neutrophil differentiation. J Biol Chem. (2004) 279:4412332. doi: 10.1074/jbc.M405883200

36. Nierhaus A, Klatte S, Linssen J, Eismann NM, Wichmann D, Hedke J, ET AL. Revisiting the white blood cell count: immature granulocytes count as a diagnostic marker to discriminate between SIRS and sepsis-a prospective, observational study. BMC Immunol. (2013) 14:8. doi: 10.1186/1471-2172-14-8

37. Pillay J, Ramakers BP, Kamp VM, Loi AL, Lam SW, Hietbrink F, et al. Functional heterogeneity and differential priming of circulating neutrophils in human experimental endotoxemia. J Leukoc Biol. (2010) 88:21120. doi: 10.1189/jlb.1209793

38. Pliyev BK, Shmidt EI, Ivanova AV, Menshikov M. Circulating CD35()$/ \mathrm{CD} 49 \mathrm{~d}(+)$ neutrophils in influenza virus infection patients. Hum Immunol. (2012) 73:1087-90. doi: 10.1016/j.humimm.2012.07.327

39. Senthilnayagam B, Kumar T, Sukumaran J, J M, Rao KR. Automated measurement of immature granulocytes: performance characteristics and utility in routine clinical practice. Patholog Res Int. (2012) 2012:483670. doi: 10.1155/2012/483670

40. Taneja R, Sharma AP, Hallett MB, Findlay GP, Morris MR. Immature circulating neutrophils in sepsis have impaired phagocytosis and calcium signaling. Shock. (2008) 30:618-22. doi: 10.1097/SHK.0b013e318173ef9c

41. Akagi T, Thoennissen NH, George A, Crooks G, Song JH, Okamoto R, et al. In vivo deficiency of both $\mathrm{C} / \mathrm{EBP} \beta$ and $\mathrm{C} / \mathrm{EBP} \varepsilon$ results in highly defective myeloid differentiation and lack of Cytokine response. PLoS ONE. (2010) 5:e15419. doi: 10.1371/journal.pone.0015419

42. Alberich-Jorda M, Wouters B, Balastik M, Shapiro-Koss C, Zhang H, Di Ruscio A, et al. $\mathrm{C} / \mathrm{EBP} \gamma$ deregulation results in differentiation arrest in acute myeloid leukemia. J Clin Invest. (2012) 122:4490-504. doi: 10.1172/JCI65102

43. Basu S, Hodgson G, Zhang HH, Katz M, Quilici C, Dunn AR. "Emergency" granulopoiesis in G-CSF-deficient mice in response to Candida albicans infection. Blood. (2000) 95:3725-33. Available online at: http://www. bloodjournal.org/content/95/12/3725.long?

44. Boettcher S, Ziegler P, Schmid MA, Takizawa H, van Rooijen N, Kopf $\mathrm{M}$, et al. Cutting edge: LPS-induced emergency myelopoiesis depends on TLR4-expressing nonhematopoietic cells. J Immunol. (2012) 188:58248. doi: 10.4049/jimmunol.1103253

45. Boxio R, Bossenmeyer-Pourie C, Steinckwich N, Dournon C, Nusse O. Mouse bone marrow contains large numbers of functionally competent neutrophils. J Leukoc Biol. (2004) 75:604-11. doi: 10.1189/jlb.0703340

46. Break TJ, Witter AR, Indramohan $M$, Mummert ME, Dory L, Berg RE. Extracellular superoxide dismutase enhances recruitment of immature neutrophils to the liver. Infect Immun. (2016) 84:3302-12. doi: 10.1128/IAI.00603-16

47. Cheung R, Shen F, Phillips JH, McGeachy MJ, Cua DJ, Heyworth PG, et al. Activation of MDL-1 (CLEC5A) on immature myeloid cells triggers lethal shock in mice. J Clin Invest. (2011) 121:4446-61. doi: 10.1172/ JCI57682

48. Evrard M, Kwok IWH, Chong SZ, Teng KWW, Becht E, Chen J, et al. Developmental analysis of bone marrow neutrophils reveals populations specialized in expansion, trafficking, and effector functions. Immunity. (2018) 48:364-79.e8. doi: 10.1016/j.immuni.2018.02.002

49. Fiedler K, Sindrilaru A, Terszowski G, Kokai E, Feyerabend TB, Bullinger $\mathrm{L}$, et al. Neutrophil development and function critically depend on Bruton tyrosine kinase in a mouse model of X-linked agammaglobulinemia. Blood. (2011) 117:1329-39. doi: 10.1182/blood-2010-04-281170

50. Hestdal K, Ruscetti FW, Ihle JN, Jacobsen SE, Dubois CM, Kopp WC, et al. Characterization and regulation of RB6-8C5 antigen expression on murine bone marrow cells. J Immunol. (1991) 147:22-8.

51. Kim MH, Yang D, Kim M, Kim SY, Kim D, Kang SJ. A late-lineage murine neutrophil precursor population exhibits dynamic changes during demandadapted granulopoiesis. Sci Rep. (2017) 7:39804. doi: 10.1038/srep39804

52. Lagasse E, Weissman IL. Flow cytometric identification of murine neutrophils and monocytes. J Immunol Methods. (1996) 197:139-50. doi: 10.1016/0022-1759(96)00138-X

53. Sanchez A, Relano C, Carrasco A, Contreras-Jurado C, MartinDuce A, Aranda A, et al. Map3k8 controls granulocyte colonystimulating factor production and neutrophil precursor proliferation in lipopolysaccharide-induced emergency granulopoiesis. Sci Rep. (2017) 7:5010. doi: 10.1038/s41598-017-04538-3

54. Ueda Y, Kondo M, Kelsoe G. Inflammation and the reciprocal production of granulocytes and lymphocytes in bone marrow. J Exp Med. (2005) 201:177180. doi: 10.1084/jem.20041419 
55. Pember SO, Barnes KC, Brandt SJ, Kinkade JM Jr. Density heterogeneity of neutrophilic polymorphonuclear leukocytes: gradient fractionation and relationship to chemotactic stimulation. Blood. (1983) 61:1105-15.

56. Hsu BE, Tabaries S, Johnson RM, Andrzejewski S, Senecal J, Lehuede $\mathrm{C}$, et al. Immature low-density neutrophils exhibit metabolic flexibility that facilitates breast cancer liver metastasis. Cell Rep. (2019) 27:390215.e6. doi: 10.1016/j.celrep.2019.05.091

57. Andzinski L, Kasnitz N, Stahnke S, Wu CF, Gereke M, von KockritzBlickwede M. et al. Type I IFNs induce anti-tumor polarization of tumor associated neutrophils in mice and human. Int J Cancer. (2016) 138:198293. doi: 10.1002/ijc. 29945

58. Coffelt SB, Kersten K, Doornebal CW, Weiden J, Vrijland K, Hau CS, et al. IL17-producing $\gamma \delta \mathrm{T}$ cells and neutrophils conspire to promote breast cancer metastasis. Nature. (2015) 522:345-8. doi: 10.1038/nature14282

59. Martin C, Burdon PC, Bridger G, Gutierrez-Ramos JC, Williams TJ, Rankin SM. Chemokines acting via CXCR2 CXCR4 control the release of neutrophils from the bone marrow and their return following senescence. Immunity. (2003) 19:583-93. doi: 10.1016/S1074-7613(03)00263-2

60. Strydom N, Rankin SM. Regulation of circulating neutrophil numbers under homeostasis and in disease. J Innate Immun. (2013) 5:30414. doi: $10.1159 / 000350282$

61. Hoglund M, Hakansson L, Venge P. Effects of in vivo administration of GCSF on neutrophil functions in healthy volunteers. Eur J Haematol. (1997) 58:195-202. doi: 10.1111/j.1600-0609.1997.tb00947.x

62. van Grinsven E, Textor J, Hustin LSP, Wolf K, Koenderman L, Vrisekoop N. Immature neutrophils released in acute inflammation exhibit efficient migration despite incomplete segmentation of the nucleus. I Immunol. (2019) 202:207-17. doi: 10.4049/jimmunol.1801255

63. Rzeniewicz K, Newe A, Rey Gallardo A, Davies J, Holt MR, Patel A, et al. Lselectin shedding is activated specifically within transmigrating pseudopods of monocytes to regulate cell polarity in vitro. Proc Natl Acad Sci USA. (2015) 112:E1461-70. doi: 10.1073/pnas.1417100112

64. Kuonen F, Laurent J, Secondini C, Lorusso G, Stehle JC, Rausch T, et al. Inhibition of the Kit ligand/c-Kit axis attenuates metastasis in a mouse model mimicking local breast cancer relapse after radiotherapy. Clin Cancer Res. (2012) 18:4365-74. doi: 10.1158/1078-0432.CCR-11-3028

65. Rice CM, Davies LC, Subleski JJ, Maio N, Gonzalez-Cotto M, Andrews $\mathrm{C}$, et al. Tumour-elicited neutrophils engage mitochondrial metabolism to circumvent nutrient limitations and maintain immune suppression. Nat Commun. (2018) 9:5099. doi: 10.1038/s41467-018-07505-2

66. Marini O, Costa S, Bevilacqua D, Calzetti F, Tamassia N, Spina C, et al. Mature $\mathrm{CD}_{10}{ }^{(+)}$and immature $\mathrm{CD} 10^{(-)}$neutrophils present in G-CSFtreated donors display opposite effects on T cells. Blood. (2017) 129:134356. doi: 10.1182/blood-2016-04-713206

67. Elghetany MT. Surface antigen changes during normal neutrophilic development: a critical review. Blood Cells Mol Dis. (2002) 28:26074. doi: $10.1006 / \mathrm{bcmd} .2002 .0513$

68. Terstappen LW, Safford M, Loken MR. Flow cytometric analysis of human bone marrow. III. Neutrophil maturation. Leukemia. (1990) 4:657-63.

69. Dransfield I, Buckle AM, Savill JS, McDowall A, Haslett C, Hogg N. Neutrophil apoptosis is associated with a reduction in CD16 (Fc gamma RIII) expression. J Immunol. (1994) 153:1254-63.

70. Yang XD, Ai W, Asfaha S, Bhagat G, Friedman RA, Jin G, et al. Histamine deficiency promotes inflammation-associated carcinogenesis through reduced myeloid maturation and accumulation of CD11b+Ly6G+ immature myeloid cells. Nat Med. (2011) 17:87-95. doi: 10.1038/nm. 2278

71. Casbon J, Reynaud D, Park C, Khuc E, Gan DD, Schepers K, et al. Invasive breast cancer reprograms early myeloid differentiation in the bone marrow to generate immunosuppressive neutrophils. Proc Natl Acad Sci USA. (2015) 112:E566-75. doi: 10.1073/pnas.1424927112

72. Waight $\mathrm{D}, \mathrm{Hu}$ Q, Miller A, Liu S, Abrams SI. Tumor-derived G-CSF facilitates neoplastic growth through a granulocytic myeloidderived suppressor cell-dependent mechanism. PLoS ONE. (2011) 6:e27690. doi: 10.1371/journal.pone.0027690

73. Fridlender ZG, Sun J, Kim S, Kapoor V, Cheng G, Ling L, et al. Polarization of tumor-associated neutrophil phenotype by TGF-beta: "N1" versus "N2" TAN. Cancer Cell. (2009) 16:183-94. doi: 10.1016/j.ccr.2009.06.017
74. McCoach CE, Rogers JG, Dwyre DM, Jonas BA. Paraneoplastic leukemoid reaction as a marker of tumor progression in non-small cell lung cancer. Cancer Treat Commun. (2015) 4:15-8. doi: 10.1016/j.ctrc.2015.03.003

75. Manz MG, Boettcher S. Emergency granulopoiesis. Nat Rev Immunol. (2014) 14:302-14. doi: 10.1038/nri3660

76. Boettcher S, Gerosa RC, Radpour R, Bauer J, Ampenberger F, Heikenwalder $M$, et al. Endothelial cells translate pathogen signals into G-CSF-driven emergency granulopoiesis. Blood. (2014) 124:1393-403. doi: 10.1182/blood-2014-04-570762

77. Semerad CL, Liu F, Gregory AD, Stumpf K, Link DC. G-CSF is an essential regulator of neutrophil trafficking from the bone marrow to the blood. Immunity. (2002) 17:413-23. doi: 10.1016/S1074-7613(02)00424-7

78. Stark MA, Huo Y, Burcin TL, Morris MA, Olson TS, Ley K. Phagocytosis of apoptotic neutrophils regulates granulopoiesis via IL-23 IL-17. Immunity. (2005) 22:285-94. doi: 10.1016/j.immuni.2005.01.011

79. Smith E, Zarbock A, Stark MA, Burcin TL, Bruce AC, Foley P, et al. IL-23 is required for neutrophil homeostasis in normal and neutrophilic mice. J Immunol. (2007) 179:8274-9. doi: 10.4049/jimmunol.179.12. 8274

80. Morris T, Khan H, Ahmad A, Weston LL, Nofchissey RA, Pinchuk IV, et al. G-CSF and G-CSFR are highly expressed in human gastric and colon cancers and promote carcinoma cell proliferation and migration. Br J Cancer. (2014) 110:1211-20. doi: 10.1038/bjc.2013.822

81. Price TH, Chatta GS, Dale DC. Effect of recombinant granulocyte colonystimulating factor on neutrophil kinetics in normal young and elderly humans. Blood. (1996) 88:335-40.

82. Wu C, Ning H, Liu M, Lin J, Luo S, Zhu W, et al. Spleen mediates a distinct hematopoietic progenitor response supporting tumor-promoting myelopoiesis. J Clin Invest. (2018) 128:3425-38. doi: 10.1172/JCI97973

83. Shaul E, Fridlender ZG. Tumour-associated neutrophils in patients with cancer. Nat Rev Clin Oncol. (2019). doi: 10.1038/s41571-019-0222-4. [Epub ahead of print].

84. Bronte V, Brandau S, Chen SH, Colombo MP, Frey AB, Greten $\mathrm{TF}$, et al. Recommendations for myeloid-derived suppressor cell nomenclature and characterization standards. Nat Commun. (2016) 7:12150. doi: $10.1038 /$ ncomms 12150

85. Damuzzo V, Pinton L, Desantis G, Solito S, Marigo I, Bronte V, et al. Complexity and challenges in defining myeloid-derived suppressor cells. Cytometry B Clin Cytom. (2015) 88:77-91. doi: 10.1002/cyto.b.21206

86. Budhwar S, Verma P, Verma R, Rai S, Singh K. The Yin and Yang of Myeloid Derived Suppressor Cells. Front Immunol. (2018) 9:2776. doi: 10.3389/fimmu.2018.02776

87. Minns D, Smith KJ, Findlay EG. Orchestration of adaptive $\mathrm{T}$ cell responses by neutrophil granule contents. Mediators Inflamm. (2019) 2019:8968943. doi: 10.1155/2019/8968943

88. Negorev D, Beier UH, Zhang T, Quatromoni JG, Bhojnagarwala P, Albelda SM, et al. Human neutrophils can mimic myeloid-derived suppressor cells (PMN-MDSC) and suppress microbead or lectin-induced $\mathrm{T}$ cell proliferation through artefactual mechanisms. Sci Rep. (2018) 8:3135. doi: 10.1038/s41598-018-21450-6

89. Davis RJ, Silvin C, Allen CT. Avoiding phagocytosis-related artifact in myeloid derived suppressor cell T-lymphocyte suppression assays. J Immunol Methods. (2017) 440:12-8. doi: 10.1016/j.jim.2016.11.006

90. Kusmartsev S, Nagaraj S, Gabrilovich DI. Tumor-associated CD8+ T cell tolerance induced by bone marrow-derived immature myeloid cells. J Immunol. (2005) 175:4583-92. doi: 10.4049/jimmunol.175.7.4583

91. Pillay J, Kamp VM, van Hoffen E, Visser T, Tak T, Lammers JW, et al. A Subset of neutrophils in human systemic inflammation inhibits $\mathrm{T}$ cell responses through Mac-1. J Clin Invest. (2012) 122:327-36. doi: 10.1172/JCI57990

92. Rahman S, Sagar D, Hanna RN, Lightfoot YL, Mistry P, Smith CK, et al. Low-density granulocytes activate T cells and demonstrate a non-suppressive role in systemic lupus erythematosus. Ann Rheum Dis. (2019) 78:95766. doi: 10.1136/annrheumdis-2018-214620

93. Andreu P, Johansson M, Affara NI, Pucci F, Tan T, Junankar S, et al. FcRgamma activation regulates inflammation-associated squamous carcinogenesis. Cancer Cell. (2010) 17:121-34. doi: 10.1016/j.ccr.2009. 12.019 
94. Tomihara K, Guo M, Shin T, Sun X, Ludwig SM, Brumlik MJ, et al. Antigen-specific immunity and cross-priming by epithelial ovarian carcinoma-induced CD11b(+)Gr-1(+) cells. J Immunol. (2010) 184:615160. doi: 10.4049/jimmunol.0903519

95. Steele CW, Karim SA, Leach JDG, Bailey P, Upstill-Goddard R, Rishi L, et al. CXCR2 inhibition profoundly suppresses metastases and augments immunotherapy in pancreatic ductal adenocarcinoma. Cancer Cell. (2016) 29:832-45. doi: 10.1016/j.ccell.2016.04.014

96. Wang D, Sun H, Wei J, Cen B, DuBois RN. CXCL1 Is Critical for premetastatic niche formation and metastasis in colorectal cancer. Cancer Res. (2017) 77:3655-65. doi: 10.1158/0008-5472.CAN-16-3199

97. Kaplan RN, Riba RD, Zacharoulis S, Bramley AH, Vincent L, Costa C, et al. VEGFR1-positive haematopoietic bone marrow progenitors initiate the pre-metastatic niche. Nature. (2005) 438:820-7. doi: 10.1038/nature 04186

98. Yang L, Huang J, Ren X, Gorska AE, Chytil A, Aakre M, et al. Abrogation of TGF beta signaling in mammary carcinomas recruits Gr$1^{+} \mathrm{CD} 11 \mathrm{~b}^{+}$myeloid cells that promote metastasis. Cancer Cell. (2008) 13:2335. doi: 10.1016/j.ccr.2007.12.004

99. Yan HH, Pickup M, Pang Y, Gorska AE, Li Z, Chytil A, et al. Gr$1+\mathrm{CD} 11 \mathrm{~b}+$ myeloid cells tip the balance of immune protection to tumor promotion in the premetastatic lung. Cancer Res. (2010) 70:613949. doi: 10.1158/0008-5472.CAN-10-0706

100. Wculek SK, Malanchi I. Neutrophils support lung colonization of metastasis-initiating breast cancer cells. Nature. (2015) 528:413-7. doi: 10.1038/nature 16140

101. Warnatsch A, Tsourouktsoglou TD, Branzk N, Wang Q, Reincke S, Herbst S, et al. Reactive oxygen species localization programs inflammation to clear microbes of different size. Immunity. (2017) 46:421432. doi: 10.1016/j.immuni.2017.02.013

102. Dupre-Crochet S, Erard M, Nubetae O. ROS production in phagocytes: why, when, and where? J Leukoc Biol. (2013) 94:657-70. doi: 10.1189/jlb. 1012544

103. Ohl K, Tenbrock K. Reactive oxygen species as regulators of MDSC-mediated immune suppression. Front Immunol. (2018) 9:2499. doi: 10.3389/fimmu.2018.02499

104. Antonio N, Bonnelykke-Behrndtz ML, Ward LC, Collin J, Christensen IJ, Steiniche $\mathrm{T}$, et al. The wound inflammatory response exacerbates growth of pre-neoplastic cells and progression to cancer. EMBO J. (2015) 34:221936. doi: 10.15252/embj.201490147

105. Brinkmann V, Reichard U, Goosmann C, Fauler B, Uhlemann Y, Weiss DS, et al. Neutrophil extracellular traps kill bacteria. Science. (2004) 303:15325. doi: 10.1126/science. 1092385

106. Park J, Wysocki RW, Amoozgar Z, Maiorino L, Fein MR, Jorns J, et al. Cancer cells induce metastasis-supporting neutrophil extracellular DNA traps. Sci Transl Med. (2016) 8:361ra138. doi: 10.1126/scitranslmed.aag1711

107. Cools-Lartigue J, Spicer J, McDonald B, Gowing S, Chow S, Giannias B, et al. Neutrophil extracellular traps sequester circulating tumor cells and promote metastasis. J Clin Invest. (2013) 123:67484. doi: 10.1158/1538-7445.AM2012-2972

108. Lee W, Ko SY, Mohamed MS, Kenny HA, Lengyel E, Naora H. Neutrophils facilitate ovarian cancer premetastatic niche formation in the omentum. $J$ Exp Med. (2019) 216:176-94. doi: 10.1084/jem.20181170

109. Lukasova E, Koristek Z, Klabusay M, Ondrej V, Grigoryev S, Bacikova A, et al. Granulocyte maturation determines ability to release chromatin NETs and loss of DNA damage response; these properties are absent in immature AML granulocytes. Biochim Biophys Acta. (2013) 1833:76779. doi: 10.1016/j.bbamcr.2012.12.012

110. Amulic B, Knackstedt SL, Abu Abed U, Deigendesch N, Harbort CJ, Caffrey BE, et al. Cell-cycle proteins control production of neutrophil extracellular traps. Dev Cell. (2017) 43:449-62.e5 doi: 10.1016/j.devcel.2017. 10.013

111. Fuchs TA, Abed U, Goosmann C, Hurwitz R, Schulze I, Wahn V, et al. Novel cell death program leads to neutrophil extracellular traps. J Cell Biol. (2007) 176:231-41. doi: 10.1083/jcb.200606027

112. Lood C, Blanco LP, Purmalek MM, Carmona-Rivera C, De Ravin SS, Smith $\mathrm{CK}$, et al. Neutrophil extracellular traps enriched in oxidized mitochondrial
DNA are interferogenic and contribute to lupus-like disease. Nat Med. (2016) 22:146-53. doi: 10.1038/nm.4027

113. Faurschou M, Borregaard N. Neutrophil granules and secretory vesicles in inflammation. Microbes Infect. (2003) 5:131727. doi: 10.1016/j.micinf.2003.09.008

114. Albrengues J, Shields MA, Ng D, Park CG, Ambrico A, Poindexter $\mathrm{ME}$, et al. Neutrophil extracellular traps produced during inflammation awaken dormant cancer cells in mice. Science. (2018) 361:aao4227. doi: 10.1126/science.aao4227

115. van Eeden SF, Kitagawa Y, Klut ME, Lawrence E, Hogg JC. Polymorphonuclear leukocytes released from the bone marrow preferentially sequester in lung microvessels. Microcirculation. (1997) 4:369-80. doi: 10.3109/10739689709146801

116. Patel S, Fu S, Mastio J, Dominguez GA, Purohit A, Kossenkov A, et al. Unique pattern of neutrophil migration and function during tumor progression. Nat Immunol. (2018) 19:1236-47. doi: 10.1038/s41590-018-0229-5

117. Lee WL, Harrison RE, Grinstein S. Phagocytosis by neutrophils. Microbes Infect. (2003) 5:1299-306. doi: 10.1016/j.micinf.2003.09.014

118. Otten MA, Rudolph E, Dechant M, Tuk CW, Reijmers RM, Beelen RH. et al. Immature neutrophils mediate tumor cell killing via IgA but not IgG Fc receptors. J Immunol. (2005) 174:5472-80. doi: 10.4049/jimmunol.174.9.5472

119. Nguyen GT, Green ER, Mecsas J. Neutrophils to the ROScue: mechanisms of NADPH oxidase activation and bacterial resistance. Front Cell Infect Microbiol. (2017) 7:373. doi: 10.3389/fcimb.2017.00373

120. Drifte G, Dunn-Siegrist I, Tissieres P, Pugin J. Innate immune functions of immature neutrophils in patients with sepsis and severe systemic inflammatory response syndrome. Crit Care Med. (2013) 41:820-32. doi: 10.1097/CCM.0b013e318274647d

121. Ventola CL. Cancer immunotherapy, Part 2: Efficacy, Safety, Other Clinical Considerations. P T. (2017) 42:452-63. Available online at: http://www. ptcommunity.com/journal/article/full/2017/7/452/cancer-immunotherapypart-2-efficacy-safety-and-other-clinical

122. Shang K, Bai YP, Wang C, Wang Z, Gu HY, Du X, et al. Crucial involvement of tumor-associated neutrophils in the regulation of chronic colitis-associated carcinogenesis in mice. PLoS ONE. (2012) 7:e51848. doi: 10.1371/journal.pone.0051848

123. Varney ML, Singh S, Li A, Mayer-Ezell R, Bond R, Singh RK. Small molecule antagonists for CXCR2 and CXCR1 inhibit human colon cancer liver metastases. Cancer Lett. (2011) 300:180-8. doi: 10.1016/j.canlet.2010. 10.004

124. Yang L, Wang B, Qin J, Zhou H, Majumdar APN, Peng F, Blockade of CCR5mediated myeloid derived suppressor cell accumulation enhances anti-PD1 efficacy in gastric cancer. Immunopharmacol Immunotoxicol. (2018) 40:9197. doi: 10.1080/08923973.2017.1417997

125. Guan Y, Zhang R, Peng Z, Dong D, Wei G, Wang Y. Inhibition of IL18-mediated myeloid derived suppressor cell accumulation enhances antiPD1 efficacy against osteosarcoma cancer. J Bone Oncol. (2017) 9:5964. doi: 10.1016/j.jbo.2017.10.002

126. Davis RJ, Moore EC, Clavijo PE, Friedman J, Cash H, Chen Z, et al. AntiPD-L1 efficacy can be enhanced by inhibition of myeloid-derived suppressor cells with a selective inhibitor of PI3K $\delta / \gamma$. Cancer Res. (2017) 77:260719. doi: 10.1158/0008-5472.CAN-16-2534

127. Kim K, Skora AD, Li Z, Liu Q, Tam AJ, Blosser RL, et al. Eradication of metastatic mouse cancers resistant to immune checkpoint blockade by suppression of myeloid-derived cells. Proc Natl Acad Sci USA. (2014) 111:11774-9. doi: 10.1073/pnas.1410626111

128. Patnaik A, Swanson KD, Csizmadia E, Solanki A, Landon-Brace N, Gehring MP, et al. Cabozantinib eradicates advanced murine prostate cancer by activating antitumor innate immunity. Cancer Discov. (2017) 7:75065. doi: 10.1158/2159-8290.CD-16-0778

129. Glodde N, Bald T, van den Boorn-Konijnenberg D, Nakamura K, O’Donnell JS, Szczepanski S, et al. Reactive neutrophil responses dependent on the receptor tyrosine kinase c-met limit cancer immunotherapy. Immunity. (2017) 47:789-802 e9. doi: 10.1016/j.immuni.2017.09.012

130. Futosi K, Mocsai A. Tyrosine kinase signaling pathways in neutrophils. Immunol Rev. (2016) 273:121-39. doi: 10.1111/imr.12455 
131. Albanesi M, Mancardi DA, Jonsson F, Iannascoli B, Fiette L, Di Santo JP, et al. Neutrophils mediate antibody-induced antitumor effects in mice. Blood. (2013) 122:3160-4. doi: 10.1182/blood-2013-04-497446

132. Ring NG, Herndler-Brandstetter D, Weiskopf K, Shan L, Volkmer JP, George $B$, et al. Anti-SIRP $\alpha$ antibody immunotherapy enhances neutrophil and macrophage antitumor activity. Proc Natl Acad Sci USA. (2017) 114:E1057885. doi: $10.1073 /$ pnas. 1710877114

133. Matlung HL, Babes L, Zhao XW, van Houdt M, Treffers LW, van Rees DJ, et al. Neutrophils kill antibody-opsonized cancer cells by trogoptosis. Cell Rep. (2018) 23:3946-59 e6. doi: 10.1016/j.celrep.2018.05.082

134. Chu D, Zhao Q, Yu J, Zhang F, Zhang H, Wang Z. Nanoparticle targeting of neutrophils for improved cancer immunotherapy. Adv Healthc Mater. (2016) 5:1088-93. doi: 10.1002/adhm.201500998

135. Hicks M, Riedlinger G, Willingham MC, Alexander-Miller MA, Von KapHerr C, Pettenati MJ, et al. Transferable anticancer innate immunity in spontaneous regression/complete resistance mice. Proc Natl Acad Sci USA. (2006) 103:7753-8. doi: 10.1073/pnas.0602382103

136. Maharaj D, Vianna PG, Ward W, Messina AJ, Rayborn T, Gouvea JV,et al. Young donor white blood cell immunotherapy induces extensive tumor necrosis in advanced-stage solid tumors. Heliyon. (2017) 3:e00438. doi: 10.1016/j.heliyon.2017.e00438

137. Peters M. Just how big is the pulmonary granulocyte pool? Clin Sci. (1998) 94:7-19. doi: 10.1042/cs0940007

138. Worthen GS, Schwab B III, Elson EL, Downey GP. Mechanics of stimulated neutrophils: cell stiffening induces retention in capillaries. Science. (1989) 245:183-6. doi: 10.1126/science. 2749255
139. Kowanetz M, Wu X, Lee J, Tan M, Hagenbeek T, Qu X, et al. Granulocytecolony stimulating factor promotes lung metastasis through mobilization of Ly6G+Ly6C+ granulocytes. Proc Natl Acad Sci USA. (2010) 107:2124855. doi: 10.1073/pnas.1015855107

140. Voloshin T, Gingis-Velitski S, Bril R, Benayoun L, Munster M, Milsom C, et al. G-CSF supplementation with chemotherapy can promote revascularization and subsequent tumor regrowth: prevention by a CXCR4 antagonist. Blood. (2011) 118:3426-35. doi: 10.1182/blood-2010-11320812

141. Pickup MW, Owens P, Gorska AE, Chytil A, Ye F, Shi C, et al. Development of aggressive pancreatic ductal adenocarcinomas depends on granulocyte colony stimulating factor secretion in carcinoma cells. Cancer Immunol Res. (2017) 5:718-729. doi: 10.1158/2326-6066.CIR-1 6-0311

Conflict of Interest Statement: The authors declare that the research was conducted in the absence of any commercial or financial relationships that could be construed as a potential conflict of interest.

Copyright (c) 2019 Mackey, Coffelt and Carlin. This is an open-access article distributed under the terms of the Creative Commons Attribution License (CC BY) The use, distribution or reproduction in other forums is permitted, provided the original author(s) and the copyright owner(s) are credited and that the original publication in this journal is cited, in accordance with accepted academic practice. No use, distribution or reproduction is permitted which does not comply with these terms. 